\title{
THE CORRELATION OF SERUM IMMUNOGLOBULIN FREE LIGHT CHAIN LEVELS AND SELECTED BIOLOGICAL MARKERS IN MULTIPLE MYELOMA
}

\author{
Tomas Pika ${ }^{a *}$, Jiri Minarik ${ }^{\mathrm{a}}$, Petr Schneiderka ${ }^{\mathrm{b}}$, Marie Budikova ${ }^{\mathrm{b}}$, Katerina Langova ${ }^{\mathrm{c}}$, \\ Pavel Lochman ${ }^{\mathrm{b}}$, Jaroslav Bacovsky ${ }^{\mathrm{a}}$, Vera Farbiakova ${ }^{\mathrm{d}}$, Vlastimil Scudla ${ }^{\mathrm{a}}$
}

\author{
a $3^{\text {rd }}$ Department of Internal Medicine, Teaching Hospital, 77520 Olomouc, Czech Republic \\ ${ }^{b}$ Department of Clinical Biochemistry, Teaching Hospital, 77520 Olomouc \\ c Department of Statistics, Palacky University Olomouc, Czech Republic \\ ${ }^{d}$ Department of Transfusion Service and Clinical Hematology, Trinec Hospital, Czech Republic \\ e-mail: tomas.pika@fnol.cz
}

Received: March 23, 2008; Accepted: April 15, 2008

Key words: Multiple myeloma/Free light chain serum levels/Biological parameters

Aims: the presented study is aimed at the evaluation of correlation of free light chains serum levels - kappa, lambda and their relation (K/L ratio) and serum levels of selected biological markers in a group of patients with multiple myeloma examined at the time of the diagnosis.

Methods: 102 patients with multiple myeloma were included in this prospective study. Free light chains serum levels were determined by Freelite ${ }^{\mathrm{TM}}$ Binding Site system, for determination of serum levels of selected parameters the following methods were used: REA thymidinekinase (TK), RIA ( $\beta_{2}$ microglobulin $\left(\beta_{2} \mathrm{~m}\right)$, ICTP, PINP), enzymoimmunoassay (sIL-6R, sVCAM-1, sICAM-1, sOPG) and quantitative enzymatic immunoassay (sHGF, sVEGF, sSyndecan-1 (sSyn-1) a sFas).

Results: There was found a correlation in the kappa-group of the dominant kappa chain and serum readings of $\beta_{2} \mathrm{~m}$ $(\mathrm{r}=0.344, \mathrm{p}=0.005)$, TK $(\mathrm{r}=0.263, \mathrm{p}=0.035)$, ICTP $(\mathrm{r}=0.402, \mathrm{p}=0.001), \operatorname{PINP}(\mathrm{r}=0.264, \mathrm{p}=0.039), \mathrm{sOPG}(\mathrm{r}=$ $0.328, p=0.028)$, sSyn-1 $(r=0.255, p=0.046)$ and $\mathrm{sFas}(\mathrm{r}=0.418, \mathrm{p}=0.001)$. In case of $\mathrm{K} / \mathrm{L}$ ratio there was found a statistically significant association of levels of $\beta_{2} \mathrm{~m}(\mathrm{r}=0.316, \mathrm{p}=0.01)$, TK $(\mathrm{r}=0.274, \mathrm{p}=0.027), \operatorname{ICTP}(\mathrm{r}=0.346, \mathrm{p}=$ 0.006), PINP ( $r=0.261, p=0.042)$, sSyn-1 $(r=0.283, p=0.026)$ and sFas $(r=0.377, p=0.002)$. In the lambda-group the analysis confirmed mutual dependence of the dominant lambda chain levels on $\beta_{2} \mathrm{~m}(\mathrm{r}=0.476, \mathrm{p}=0.003)$, ICTP $(\mathrm{r}=0.375, \mathrm{p}=0.022)$, sVCAM-1 $(\mathrm{r}=0.383, \mathrm{p}=0.019)$, $\mathrm{sHGF}(\mathrm{r}=0.441, \mathrm{p}=0.006)$ and $\mathrm{sFas}(\mathrm{r}=0.334, \mathrm{p}=0.040)$. In addition we ascertained a correlation of $\mathrm{L} / \mathrm{K}$ ratio and levels of $\beta_{2} \mathrm{~m}(\mathrm{r}=-0.473, \mathrm{p}=0.003)$, TK $(\mathrm{r}=-0.412, \mathrm{p}=$ 0.011), ICTP ( $r=-0.331, p=0.045)$, PINP $(r=-0.409, p=0.012)$, sHGF $(r=-0.357, p=0.028)$, sSyn-1 $(r=-0.449$, $\mathrm{p}=0.005)$ a sFas $(\mathrm{r}=-0.371, \mathrm{p}=0.022)$.

Conclusions: The study confirmed mutual correlation of FLC serum levels and the levels of several selected biological markers, in particular $\beta_{2} \mathrm{~m}$, TK, ICTP, PINP, sSyn-1 a sFas at time of the diagnosis. It referred to the mutual relation of bone marrow microenvironment, biological qualities of clonal plasmocytes and the intensity of the free light chains production by the tumour cell population.

\section{INTRODUCTION}

Multiple myeloma (MM) is a malignant hematological disease characterised by the uncontrolled proliferation and accumulation of neoplastically transformed plasma cells, production of monoclonal immunoglobulin (MIG) detectable in the serum and/or urine and various degrees of organ involvement (hypercalcemia, renal insufficiency, osteolytic bone lesions or osteoporosis, anemia and immunodeficiency $)^{1,2}$. Apart from the complete molecule of monoclonal immunoglobulin, the plasma cells also produce single free light chains (FLC) which are not fixed to the MIG molecule ${ }^{3}$. In the last few years, the assessment of free light chain serum levels has become an irreplaceable part of the examination algorithm in diagnostics, screening and evaluation of treatment response not only in patients with multiple myeloma but also in other malignant or potentially malignant monoclonal gammopathies $^{4-6}$. The bone marrow microenvironment in relation to the pathological plasmacellular infiltration is characterised by a very large system of intercellular and cytokine interactions among the stromal cells of bone marrow, bone elements and tumour cells themselves, in close relation to their own biological qualities of the disease $^{7}$. Some unusual biochemical parameters appear to be very promising as possible future markers not only in the neoplastic transformation of potential malignant monoclonal gammopathy of undetermined significance (MGUS) and its differentiation from the early stage MM but also as markers of advanced stage, progression and monitoring of treatment response in patients with multiple myeloma ${ }^{8-10}$. The aim of this study was to determine the relation of FLC serum levels to 12 selected less usual biological parameters in patients with multiple myeloma who were examined at the time of diagnosis. 


\section{MATERIALS AND METHODS}

The sample studied included 102 patients examined at the time of diagnosis and who fulfiled the SWOG and IMWG criteria for multiple myeloma diagnosis ${ }^{11}$. The age range was $43-82$, median 63 years, men and women ratio $1: 1.04$. Immunochemical type IgG was found in $58 \%$ $(\mathrm{n}=60), \operatorname{IgA} 22 \%(\mathrm{n}=22)$, Bence - Jones $17 \%(\mathrm{n}=17)$, $\operatorname{IgD} 1 \%(\mathrm{n}=1)$ and nonsecretoric type $2 \%(\mathrm{n}=2)$. The kappa light chain secretion was found in $68 \%(\mathrm{n}=69)$ and lambda secretion in $32 \%(n=33)$ of patients. With the use of Durie-Salmon staging system there $12 \%(n=12)$ of patients were in stage I, $28 \%(n=29)$ in stage II and $60 \%(n=61)$ in stage III. The A substage (creatinine under $177 \mu \mathrm{mol} / \mathrm{l}$ ) was found in $75 \%$ of patients ${ }^{12}$. Using the International Prognostic Index (IPI) staging system $12 \%$ $(n=12)$ of patients were in the 1st stage, $22 \%(n=22)$ in the 2 nd stage and $66 \%(n=68)$ in the 3 rd stage $^{13}$. Serum levels of free light chains were set by the Freelite ${ }^{\mathrm{TM}}$ Binding Site system (Immunotech, standard serum interval: kappa 3.3-19.4 mg/l, lambda 5.7-26.3 mg/1, lambda /kappa (K/L ratio) 0.26-1.65) (ref. $\left.{ }^{3}\right)$. Serum levels were determined by the following methods: $\beta_{2}$ microglobulin $(\beta, \mathrm{m})$ by the radioimmunoanalysis method (RIA, standard range $0-2.5 \mathrm{mg} / 1$ ), tymidine kinase (TK) by radioenzymatic method (REA, 0-6 IU/1), intercellular C-terminal telopeptide collagen-I (ICTP, m: 2.1-5.0, w: 2.1-5.6 $\mu \mathrm{g} / \mathrm{l}$ ) and N-terminal peptide procollagen-I (PINP, m: 21-78, w: 19-102 $\mu \mathrm{g} / \mathrm{l}$ ) by RIA method; vascular cell adhesive molecule-1 (sVCAM, 395-714 ng/ml), intercellular cell adhesive molecule-1 (sICAM, 269-691 ng/ml), solubile form of IL-6R (sIL-6R, 10-90 ng/ml) and solubile osteoprotegerine (sOPG, 3.7-4.4 $\mu \mathrm{mol} / 1$ ) by enzymeimmunoassay method; hepatocyte growth factor (sHGF, 671-1992 pg/ml), vascular endothelial growth factor (sVEGF, 62-707 pg/ml), syndecan-1/sCD138 (sSyn-1, 37-123 ng/ml) and Fas antigen (sFas $4792-1750 \mathrm{pg} / \mathrm{ml}$ ) were determined by a quantitative sandwich enzymatic immunoassay method. For statistical evaluation the Spearman Rank Correlation Coefficient test was used. Kappa and lambda secretion, respectively kappa and lambda groups were assessed separately due to the reciprocal relation of serum levels and $\mathrm{K} / \mathrm{L}$ ratio of free chains.

\section{RESULTS}

Abnormal serum levels of free light chains were recorded in $92 \%$ of patients and, a pathological $\mathrm{K} / \mathrm{L}$ ratio was found in $91 \%$ cases. Abnormal $\beta_{2} \mathrm{~m}$ levels were recorded in $95.1 \%$, in TK in $58.8 \%$, sIL-6R in $68.6 \%$, sVCAM in $74 \%$, sICAM in $32.6 \%$, ICTP in $72.7 \%$, PINP in $21 \%$; abnormal levels (under and above standard interval) were recorded in case of sOPG in $97.3 \%$, sHGF in $39.3 \%$, sVEGF in $7.7 \%$, sSyn- 1 in $69.4 \%$ and in case of sFas antigen in $3.8 \%$. A significant correlation of serum levels of the kappa dominant chain and serum levels of $\beta_{2} \mathrm{~m}(\mathrm{r}=0.344, \mathrm{p}=0.005)$, TK $(\mathrm{r}=0.263, \mathrm{p}=0.035)$, $\operatorname{ICTP}(r=0.402, p=0.001), \operatorname{PINP}(r=0.264, p=0.039)$,
sOPG $(r=0.328, p=0.028)$, sSyn- $1(r=0.255, p=0.046)$ and $\mathrm{sFas}(\mathrm{r}=0.418, \mathrm{p}=0.001)$ were found. In the case of the $\mathrm{K} / \mathrm{L}$ ratio and particular parameter assessment, a correlation of the levels of $\beta_{2} \mathrm{~m}(\mathrm{r}=0.316, \mathrm{p}=0.01)$, TK $(r=0.274, p=0.027)$, ICTP $(r=0.346, p=0.006)$, PINP $(r=0.261, p=0.042)$, sSyn-1 $(r=0.283, p=0.026)$ and $\mathrm{sFas}(\mathrm{r}=0.377, \mathrm{p}=0.002)$. In the lambda group the correlation analysis confirmed mutual dependence of the dominant lambda chain level and levels of $\beta_{2} \mathrm{~m}(\mathrm{r}=0.476$, $\mathrm{p}=0.003)$, ICTP $(\mathrm{r}=0.375, \mathrm{p}=0.022)$, sVCAM-1 $(\mathrm{r}=0.383, \mathrm{p}=0.019)$, sHGF $(\mathrm{r}=0.441, \mathrm{p}=0.006)$ and sFas $(r=0.334, p=0.040)$. Likewise, an association of $\mathrm{K} / \mathrm{L}$ ratio and the levels of $\beta \mathrm{m}(\mathrm{r}=-0.473, \mathrm{p}=0.003)$, TK $(r=-0.412, p=0.011)$, ICTP $(r=-0.331, p=0.045)$, PINP $(r=-0.409, p=0.012)$, sHGF $(r=-0.357$, $\mathrm{p}=0.028)$, sSyn-1 $(\mathrm{r}=-0.449, \mathrm{p}=0.005)$ and $\mathrm{sFas}(\mathrm{r}=$ $-0.371, p=0.022)$ was revealed. No significant correlation of alternative chain levels and monitored parameters levels was found for any of the groups.

\section{DISCUSSION}

The results show the mutual relation of serum levels of FLC, K/L ratio and selected untraditional markers of multiple myeloma. The abnormal percentage of serum free light chain levels and $\mathrm{K} / \mathrm{L}$ ratio for the analysed group approximately corresponds to previously published studies which have reported comparable pathological percentages of FLC even if there was a higher percentage in the case of the $\mathrm{K} / \mathrm{L}$ ratio than FLC levels themselves in most studies $^{4,14,15}$. The correlation of FLC serum levels, K/L ratio and $\beta_{2} \mathrm{~m}$ levels not only results from the biological qualities of both parameters (level increase in case of renal insuficiency, polymerization), but also both parameters are markers of the size of the tumour mass. The interval levels of $\beta_{2} \mathrm{~m}$, the most important prognostic factor in multiple myeloma, are the new staging systems components - International Prognostic Index (IPI), South-West Oncology Group (SWOG) (ref. ${ }^{12,16}$ ); there was a correlation of these system stages and FLC levels, also the combination of IPI system and serum levels of FLC and K/L ratio appears to be very promising prognostic marker ${ }^{17-20}$. The relation of FLC and serum tymidinekinase as proliferation markers and as tumour mass markers is explainable as well; an association was found of FLC serum levels and OLOMOUC staging system phases in which $\beta, \mathrm{m}$ and TK serum levels were used ${ }^{21-23}$. The detected relation of the bone metabolism parameters ICTP, PINP and FLC levels can also be explained by the association of these markers to the stage of bone involvement and also to the progress and prognosis of the disease ${ }^{24,25}$. Detected relation of FLC, K/L ratio serum levels and Syndecan-1 confirms the unique position of this less usual parameter. Syndecan- 1 is a proteoglycan released from the surface of viable malignant plasma cells, mainly concerned with the proliferation process, apoptosis of tumour and also bone cells and relating bone involvement; influences the cytokine net in direct and indirect way in conditions of 
the bone marrow microenvironment. It is considered to be one of the most important molecules in the multiple myeloma pathobiology ${ }^{26}$. Syndecan-1 appears to be a new important prognostic marker, also a possible parameter for discernment of monoclonal gammopathy of undetermined significance and multiple myeloma ${ }^{8,9,27-29}$.

Detected correlation of FLC, K/L ratio and sFas levels is now more of the academical meaning which would be observed. Solubile Fas antigen is a part of antiapoptotic mechanisms participating in the immortality of tumour cell line ${ }^{30}$.

\section{CONCLUSIONS}

The results confirm the relation of serum levels of free light chain kappa, resp. lambda and $\mathrm{K} / \mathrm{L}$ ratio and several less usual parameters in multiple myeloma. The study confirmed the association with tumour mass, biolocal qualities of myeloma cells, parameters of bone metabolism, myeloma bone disease and the bone marrow microenvironment itself. The conclusions of the study give source materials for use of less usual markers for distinguishing monoclonal gammopathy of undetermined significance from multiple myeloma and for evaluation of progress and treatment response in patients with MM. Kappa/Lambda ratio particularly seems to be more sensitive marker than free light chains levels.

\section{ACKNOWLEDGEMENT}

Supported by IGA MZ CR NR/9500-3 and VVZ MSM 619895205.

\section{REFERENCES}

1. Dispenzieri A, Lacy M Q, Greipp PR. Multiple Myeloma, p. 54 In: Gertz MA, Greipp PR: Multiple myeloma and related plasma cell disorders. Springer, Heidelberg, 2004.

2. Adam Z, Scudla V, Neubauer J. Mnohocetny myelom. In: Adam $\mathrm{Z}$, Vorlicek $\mathbf{J}$ et al. Hematologie II. Prehled malignich hematologickych nemoci. Praha, Grada publishing 2001: p. 461-502.

3. Bradwell AR. Serum free light chain analysis, 4th edition, p. 12-21. The Binding site, Birmingham, 2006.

4. Scudla V, Minarik M, Schneiderka P, Kouril M, Kapustova M, Vytrasova $M$ et al. Vyznam stanoveni serovych hladin volnych lehkych retezcu imunoglobulinu v diagnostice a hodnoceni aktivity mnohocetneho myelomu a vybranych monoklonalnich gamapatii. Vnitr Lek 2005; 51(11): 249-1259.

5. Bradwell AR. Serum free light chain measurements move to center stage. Clin Chem 2005; 51(5):805-807.

6. Mayo MM, Johns GS. Serum free light chains in the diagnosis and monitoring of patients with plasma cell dyscrasias. Contrib Nephrol 2007; 153:44-65.

7. Bacovsky J, Scudla V. Cytokinova sit u mnohotneho myelomu. Vnitr Lek 1994; 40 (8):517-520.

8. Englis M. Stanoveni volnych lehkych retezcu imunoglobulinu v seru $\mathrm{v}$ diagnostice a monitorovani monoklonalnich gamapatii. http:// www.cskb.cz/vzdelavani/light_chain.htm

9. Scudla V, Pika T, Budikova M, Ordeltova M, Minarik J, Zemanova $\mathrm{M}$ et al. Prispevek $\mathrm{k}$ hodnoceni vztahu angiogennich cytokinu a vybranych biologickych ukazatelu k prognostickym faktorum mnohocetneho myelomu. Cas Lek Ces 2006; 145:929-935.

10. Scudla V, Pika T, Budikova M, Ordeltova M, Minarik J, Zemanova $\mathrm{M}$ et al. Evaluation of selected biological parameters in stages of multiple myeloma examined according to Durie-Salmon (D-S) and International Prognostic Index (IPI). Haematologica 2007; 92(S2):115-116.

11. International myeloma working group criteria for the classification of monoclonal gammapathies, multiple myeloma and related disorders: a report of the International Myeloma Working Group. Br J Hemat 2003; 121:749-757.

12. Durie BGM, Salmon SE. A clinical staging system for multiple myeloma. Cancer 1975; 36:824-854.

13. Greipp PR, San Miguel J, Durie BGM, Crowley JJ, Barlogie B, Blade $\mathrm{J}$ et al. International staging system for multiple myeloma. $\mathrm{J}$ Clin Oncol 2005; 23:3412-3420.

14. Mead GP, Carr-Smith HD, Drayson MT, Bradwell AR. Serum free light chain levels in patients with intact immunoglobulin myeloma. Clin Chem 2003; 49:A107, D-61.

15. Katzmann JA, Abraham RS, Dispenzieri A, Lust JA, Kyle RA. Diagnostic performance of quantitative kappa and lambda free light chain assays in clinical practice. Clin Chem 2005; 51:5,878881.

16. Jacobson JL, Hussein MA, Barlogie B, Durie BGM, Crowley JJ. A new staging system for multiple myeloma pacients based on the Southwest Oncology Group experience. Brit J Hemat 2003; 122:441-450.

17. Pika T, Zemanova M, Minarik J, Schneiderka P, Bacovsky J, Scudla V. A relationship of serum imunoglobulin free light chain levels measurement to multiple myeloma staging. Trans Hemat dnes 2007; 13(1):12-15.

18. Nowrousian MR, Brathorst D, Sammet C, Kellert M, Daniels R, Schuett $P$ et al. Serum free light chain analysis and urine immunofixation electrophoresis in patients with multiple myeloma . Clin Cancer Res 2005; 11(24):8706-8714.

19. Kyrtsonis MC, Vassilakopoulos TP, Kafasi N, Anagnostopoulos A, Delimpasi S, Terpos E et al. Prognostic implification of the combination SFLCR and ISS in MM. Haematologica 2007; 92 (s2),207.

20. Kyrtsonis MC, Vassilakopoulos TP, Kafasi N, Maltesas D, Anagnostopoulos A, Terpos E et al. The addition of sFLCR improves ISS prognostication in multiple myeloma. ASH 2007, Abstract No 1490.

21. Scudla V, Bacovsky J, Vytrasova M, Ordeltova M, Budikova M, Papajik T et al. Prognosticke faktory a klinicke stazovaci systemy u mnohocetneho myelomu v souboru 237 nemocnych lecenych v obdobi 1991-2002 konvencni chemoterapii. Klin Onkol 2002; 15(Suppl.):7-14.

22. Pika T, Zemanova M, Minarik J, Langova K, Scudla V. Vztah serovych hladin volnych lehkych retezcu imunoglobulinu ke stupni progrese mnohocetneho myelomu. Vnitr Lek 2006; 52(11):1120, Abstract No 56.

23. Scudla V, Bacovsky J, Papajik T, Budikova M, Srovnalik K. Tymidinkinaza sera u mnohotneho myelomu. Vztah $\mathrm{k}$ vybranym laboratornim ukazatelum nemoci. Vnitr Lek 1994; 40:151-156.

24. Abildgaard N, Bentzen SM, Nielsen JL, Heickendorff L. Serum markers of bone metabolism in multiple myeloma: Prognostic value of the carboxy-terminal telopeptide of type I collagen. Brit. J. Hematol. 1997; 96:103-110.

25. Bacovsky J, Scudla V, Vytrasova M, Budikova M, Myslivecek M. Monitoring of bone resorption and bone formation in multiple myeloma. Biomed Papers 2002; 146(2):59-61.

26. Dhodapkar MV, Sanderson RD. Syndecan-1 (CD 138) in myeloma and lymphoid malignancies: A multifunctional regulator of cell behavior within the tumor microenviroment. Leuk Lymph 1999; 34:35-43.

27. Kyrtsonis MC, Vassilakopoulos TP, Siakantaris MP, Kokoris SI, Gribabis DA, Dimopoulou MK et al. Serum syndecan-1, basic fibroblast growth factor and osteoprotegerin in myeloma patients at diagnosis and during the course of the disease. Eur J Haematol 2004; 72:252-258. 
28. Schaar CG, Vermeer HJ, Wijermans PW, Huisman W, Cessie S, Kluin-Nelemans HC. Serum syndecan-1 in patients with newly diagnosed monoclonal proteinemia. Haematologica 2005; 90:14371438.

29. Seidel C, Sundan A, Hjorth M, Turesson I, Dahl IMS, Abildgaard $\mathrm{N}$ et al. Serum syndecan-1: a new independent prognostic marker in multiple myeloma. Blood 2000; 95:388-392.
30. Shima Y, Nishimoto N, Ogata A, Fujii Y, Yoshizaki K, Kishimoto T. Myeloma cell express Fas antigen/APO-1 (CD95) but only some are sensitive to anti-Fas antibody resulting in apoptosis. Blood $1995 ; 85: 757-764$. 